\title{
A MECHANISM FOR LH-INDUCED REGRESSION OF CORPORA LUTEA IN RABBITS
}

\author{
P. L. KEYES* AND A. V. NALBANDOV \\ Department of Animal Science-Genetics, \\ University of Illinois, Urbana, Illinois, U.S.A.
}

(Received 27th March 1968)

\begin{abstract}
Summary. An explanation is proposed for the fact that luteinizing hormone (LH) injected into intact pseudopregnant rabbits acts in a luteolytic manner while in hypophysectomized rabbits it acts like a luteotrophin. Recent evidence shows that oestrogen is both luteotrophic and steroidogenic in rabbits. It is pointed out that injection of $\mathrm{LH}$ into intact rabbits causes ovulation of follicles which presumably serve as the endogenous source of oestrogen. In the absence of endogenous oestrogen, corpora lutea degenerate. In hypophysectomized rabbits, follicles do not ovulate in response to LH, and the latter is assumed to cause the unovulated follicles to secrete oestrogen which in turn acts in a luteotrophic manner on the corpora lutea.
\end{abstract}

It has been noted by Stormshak \& Casida (1964) that the injection of a single dose of $\mathrm{LH}(50 \mu \mathrm{g})$ into rabbits causes the regression of corpora lutea (CL) of pseudopregnancy. At the same time $\mathrm{LH}$ has been found to be luteotrophic in hypophysectomized rabbits (Kilpatrick, Armstrong \& Greep, 1964). It has been suggested (Stormshak \& Casida, 1965) that LH may cause luteal regression in combination with a luteolytic substance possibly of pituitary origin or that it may interfere with the secretion of oestrogen by the ovarian interstitial tissue (Spies, Coon \& Gier, 1966). The first suggestion has no proof, and the second is untenable because interstitial tissue is known not to produce oestrogen in physiologically measurable quantities (Lacassagne, Duplan, Marcovich \& Raynaud, 1962). Nevertheless, it is true that the LH-induced regression of corpora lutea can be prevented by oestrogen (Stormshak \& Casida, 1965; Spies et al., 1966). In these studies the amounts of oestrogen used were unphysiologically large: in one case, $1.0 \mathrm{mg} /$ day (Spies et al., 1966) and in the other, $30 \mu \mathrm{g} /$ day (Stormshak \& Casida, 1965). More recently, Keyes \& Nalbandov (1967) have shown: (a) that normal corpora lutea regress very rapidly if follicles are destroyed by X-irradiation of the ovary; (b) that in the absence of follicles, which are the presumed source of oestrogen, the corpora lutea neither synthesize nor secrete progesterone; and (c) that, in the absence of follicles, the regression of corpora lutea can be prevented by the systemic injection of oestradiol-17 $\beta$ (2 to $4 \mu \mathrm{g} / \mathrm{day}$ ) into does weighing 3 to $5 \mathrm{~kg}$. On the basis of this last report we believe it is now possible to offer an explanation

* Present address: Endocrinology Research Laboratories, Shields Warren Radiation 50 Binney Street, Boston, Massachusetts 02115, U.S.A. 
for the seeming paradox of LH being luteolytic in intact pseudopregnant rabbits and luteotrophic after hypophysectomy.

Normally the ovary of pseudopregnant (or pregnant) rabbits contains both CL and follicles. Presumably these follicles secrete oestrogen and it is postulated that this endogenous oestrogen is sufficient to exert a luteotrophic (and steroidogenic) effect on the neighbouring cL. If a single dose of $L H$ is given which is sufficient to cause ovulation or luteinization of the majority of follicles present, the endogenous source of oestrogen is thus foreclosed, resulting in rapid degeneration of all cL. That CL degenerate due to absence of oestrogen and not because of luteolytic substances is supported by the following experiment. Twelve New Zealand white does $(3.2$ to $5.0 \mathrm{~kg})$ were mated to sterile bucks, and, on Days 11 or 12 of pseudopregnancy, eight were laparotomized and the cL. were counted and marked with carbon black. On Day 13 these eight does were each given an intravenous injection of $100 \mu \mathrm{g}$ NIH-LH-s7; four does received no further treatment and four received daily subcutaneous injections of oestradiol-17 $\beta(3 \mu \mathrm{g} /$ day, injections every $8 \mathrm{hr})$ in corn oil. All twelve does were autopsied on Day 16 of pseudopregnancy, and the original CL in each ovary were weighed together on a torsion balance and an average corpus luteum weight computed. Inspection of ovaries revealed that all does had ovulated in response to injection of $\mathrm{LH}$. The average corpus luteum weights are as follows: intact pseudopregnant, $15.9 \pm 0.5$ ( \pm S.E.); LH and oestrogen, $18 \cdot 8 \pm 1 \cdot 1 ; \mathrm{LH}$ alone, $7 \cdot 5 \pm 0 \cdot 3$. It is clear from these results that $\mathrm{LH}$ caused regression of original $\mathrm{CL}$ and that oestradiol prevented this regression. In a previous study (Keyes \& Nalbandov, 1967), this same dose of oestradiol was an effective luteotrophic substitute for follicles destroyed by X-irradiation, and it was physiologically compatible with the maintenance of pregnancy.

In the hypophysectomized pseudopregnant rabbit there is a dichotomy of LH action. If LH is given immediately after hypophysectomy it is luteolytic (Kilpatrick et al., 1964). This effect is ascribed to the fact that, at this time, the ovarian follicles can and do ovulate. If $\mathbf{L H}$ is given somewhat later, it becomes luteotrophic (Kilpatrick et al., 1964). At this time the follicles have lost their ability to ovulate and the luteotrophic effect can be ascribed to the ability of LH to stimulate these unovulated follicles to secrete oestrogen which in turn has the luteotrophic effect typical of oestrogen.

The proposed interpretation is based on the demonstrated fact that physiological doses of oestrogen are luteotrophic in rabbits (Robson, 1939; Keyes \& Nalbandov, 1967), and it has the advantage in that it does not invoke the hypothetical action of a luteolytic substance of uterine or of hypophysial origin which has not been demonstrated to exist. It does make use of established facts and phenomena most of which have been verified experimentally. In view of the exceedingly small amounts of oestrogen which were found to be luteotrophic ( $3 \mu \mathrm{g} / 5.0 \mathrm{~kg}$ of rabbit injected systemically), it also appears that the mechanism proposed is physiological and compatible with the small quantities of oestrogen which are likely to be secreted by small follicles in the presence of corpora lutea. This oestrogen effect may be purely local and normally not predicated on the presence of oestrogen in the peripheral circulation. 
This study was supported by NIH predoctoral fellowship (1F1-GM-29, 903) to P. L. Keyes and by NIH research grant AM 06976.

\section{REFERENCES}

Keyes, P. L. \& NALBANDov, A. V. (1967) Maintenance and function of corpora lutea in rabbits depend on estrogen. Endocrinology, 80, 938.

Kilpatrick, R., Armstrong, D. T. \& Greep, R. O. (1964) Maintenance of the corpus luteum by gonadotrophins in the hypophysectomized rabbit. Endocrinology, 74, 453.

Lacassagne, A., Duplan, J. F., Marcovich, H. \& Raynaud, A. (1962) The action of ionizing radiations on the mammalian ovary. In: The Ovary, Vol. 11, p. 478. Ed. S. Zuckerman. Academic Press, New York.

Rosson, J. M. (1939) Maintenance of pregnancy in the hypophysectomized rabbit by the administration of oestrin. F. Physiol., Lond. 95, 83.

SpIEs, H. G., CoON, L. L. \& GIER, H. T. (1966) Luteolytic effect of LH and HCG on the corpora lutea of pseudopregnant rabbits. Endocrinology, 78, 67.

Stormshak, F. \& CAsida, L. E. (1964) Effect of gonadotropins on corpora lutea of pseudopregnant rabbits. Endocrinology, 75, 321.

Stormshak, F. \& CASIDA, L. E. (1965) Effects of LH and ovarian hormones on corpora lutea of pseudopregnant and pregnant rabbits. Endocrinology, 77, 337. 